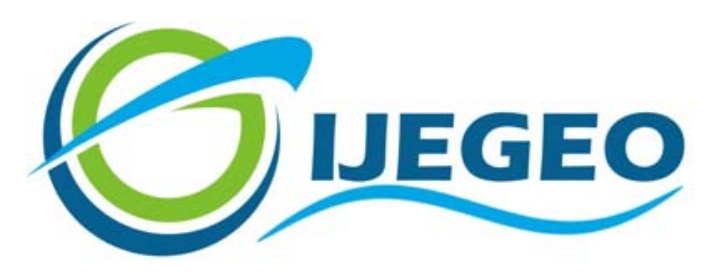

International Journal of Environment and Geoinformatics (IJEGEO) is an international, multidisciplinary, peer reviewed, open access journal.

\title{
Heavy metals analysis of the limpet Cellana karachiensis (Winckworth 1930) from two rocky shores of the Karachi coasts of Pakistan
}

\section{Fatima Hayat Shaheen ZAFAR, Levent BAT, Sidrah MEHMOOD, Syed Ikhlaq HUSSAIN}

\author{
Chief in Editor \\ Prof. Dr. Cem Gazioğlu \\ Co-Editors \\ Prof. Dr. Dursun Zafer Şeker, Prof. Dr. Şinasi Kaya, \\ Prof. Dr. Ayşegül Tanık and Assist. Prof. Dr. Volkan Demir
}

Editorial Committee (April 2020)

\begin{abstract}
Assos. Prof. Dr. Abdullah Aksu (TR), Assit. Prof. Dr. Uğur Algancı (TR), Prof. Dr. Bedri Alpar (TR), Prof. Dr. Lale Balas (TR), Prof. Dr. Levent Bat (TR), Prof. Dr. Paul Bates (UK), İrşad Bayırhan (TR), Prof. Dr. Bülent Bayram (TR), Prof. Dr. Luis M. Botana (ES), Prof. Dr. Nuray Çağlar (TR), Prof. Dr. Sukanta Dash (IN), Dr. Soofia T. Elias (UK), Prof. Dr. A. Evren Erginal (TR), Assoc. Prof. Dr. Cüneyt Erenoğlu (TR), Dr. Dieter Fritsch (DE), Assos. Prof. Dr. Çiğdem Göksel (TR), Prof.Dr. Lena Halounova (CZ), Prof. Dr. Manik Kalubarme (IN), Dr. Hakan Kaya (TR), Assist. Prof. Dr. Serkan Kükrer (TR), Assoc. Prof. Dr. Maged Marghany (MY), Prof. Dr. Michael Meadows (ZA), Prof. Dr. Nebiye Musaoğlu (TR), Prof. Dr. Erhan Mutlu (TR), Prof. Dr. Masafumi Nakagawa (JP), Prof. Dr. Hasan Özdemir (TR), Prof. Dr. Chryssy Potsiou (GR), Prof. Dr. Erol Sarı (TR), Prof. Dr. Maria Paradiso (IT), Prof. Dr. Petros Patias (GR), Prof. Dr. Elif Sertel (TR), Prof. Dr. Nüket Sivri (TR), Prof. Dr. Füsun Balık Şanlı (TR), Prof. Dr. Uğur Şanlı (TR), Duygu Ülker (TR), Assoc. Prof. Dr. Oral Yağcı (TR), Prof. Dr. Seyfettin Taş (TR), Assoc. Prof. Dr. Ömer Suat Taşkın (US), Dr. İnese Varna (LV), Dr. Petra Visser (NL), Prof. Dr. Selma Ünlü (TR), Assoc. Prof. Dr. İ. Noyan Yılmaz (AU), Prof. Dr. Murat Yakar (TR), Assit. Prof. Dr. Sibel Zeki (TR)
\end{abstract}

Abstracting and Indexing: TR DIZIN, DOAJ, Index Copernicus, OAJI, Scientific Indexing Services, International Scientific Indexing, Journal Factor, Google Scholar, Ulrich's Periodicals Directory, WorldCat, DRJI, ResearchBib, SOBIAD 


\title{
Heavy metals analysis of the limpet Cellana karachiensis (Winckworth 1930) from two rocky shores of the Karachi coasts of Pakistan
}

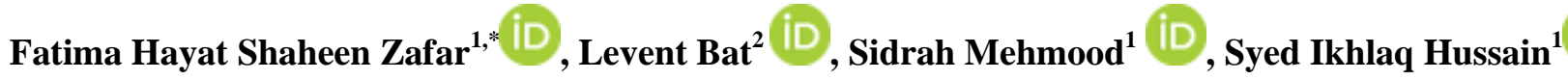 \\ ${ }^{1}$ Department of Zoology, Federal Urdu University of Arts, Science and Technology, Karachi-75270, Pakistan \\ ${ }^{2}$ Sinop University Fisheries Faculty, Department of Hydrobiology, TR57000 Sinop, Turkey

How to cite: Zafar et al., (2020). Heavy metals analysis of the limpet Cellana karachiensis (Winckworth 1930) from two rocky shores of the Karachi coasts of Pakistan, International Journal of Environment and Geoinformatics (IJEGEO), 7(1): 80-87 DOI: 10.30897/ijegeo.683454

\begin{abstract}
In current years, observing the concentration of heavy metals in marine biota has received much awareness as the public are more aware about the healthy environment and food. Intensity of these metals in a huge range of finfish and shellfish would give baseline information for some of the toxic metals. In the present investigation an attempt has been made to study the presence and concentration of some heavy metals in the true limpet Cellana karachiensis a gastropod mollusk which is abundantly found at the intertidal to high tidal zones of different rocky shores of Sind and Baluchistan coasts of Pakistan. In the present study two distinct anthropogenic dynamic rocky shores i.e., Clifton and Mubarak village of Karachi coast was selected to analyse the heavy metals in soft tissues of $C$. karachiensis which accept as a good bio-indicator mollusk to observe heavy metal pollution awareness. The concentration of zinc $(\mathrm{Zn})$, chrome $(\mathrm{Cr})$, copper $(\mathrm{Cu})$, lead $(\mathrm{Pb})$ and cadmium $(\mathrm{Cd})$ in the soft tissue of the limpet $C$. karachiensis from two rocky shores in the Karachi coast has been measured by Atomic Absorption Spectrometer (A Analyst 700) for monitoring metal contamination of samples. Accumulation of $\mathrm{Zn}$ was found highest followed by $\mathrm{Cr}, \mathrm{Cu}, \mathrm{Pb}$ and $\mathrm{Cd}$ in the months of July and August 2019 in Clifton shores. While at the same period the highest concentration was $\mathrm{Zn}$ followed by $\mathrm{Cu}, \mathrm{Cd}, \mathrm{Cr}$ and $\mathrm{Pb}$ at $\mathrm{Mub}$ arak village shore. It has been observed that, $C$. karachiensis at Clifton shore accumulated more than heavy metals that found at Mubarak village shore. The pattern of accumulation of Heavy metals at both sites of limpets did not exhibit much difference. ANOVA single factor and student $t$ test was done for the statistical analysis of metal contents in soft tissues of C. karachiensis of both shores at $(\mathrm{p}<0.01)$ and observed statistically significant differences in the amounts of the $\mathrm{Cu}, \mathrm{Cd}$ and $\mathrm{Zn}$ elements among the limpets of both rocky shores. Same as the significant result at $p<0.01$ and $p<0.05$ was observed in between the length size of limpets at Clifton and Mubarak Village rocky shores. Correlation studies carried out for the metal concentrations in limpet and shell length of the animal which did not show significant results except $\mathrm{Cu}$ at Mubarak village shore. The results were compared with previous studies and discussed.
\end{abstract}

Keywords: Cellana karachiensis, Bioindicator, Metals, Karachi Coast, the NE Arabian Sea

\section{Introduction}

The incredible exaggerate in the expansion of mankind community and the following openings out of industries have implication in the haphazard use of various injurious chemical products, pesticides and herbicides. The constant discharge of these harmful substances into the atmosphere has mainly malformed the coastal zones as well marine ecosystem into an area, which is extremely in danger to the toxic effects of these toxic waste (Vallaeys et al., 2017). During the last decades, the condition of oceanic environment, in stipulations of environmental pollution, has turn into an issue of rising global apprehension (Kelepertzis, 2013). Oceans supply main possessions for rapidly rising inhabitants all over the world. Ocean sustainability thus set up a key substance for human health, in addition to financial and environmental point of view (Burak et al., 2004; Kumar \& Achyuthan, 2007). Heavy metals set out in the course of anthropogenic actions locate their approach into the marine environment through the fresh water or direct fallout from industrial waste matters. These heavy metals resuspend back into the water column along with the sediments and are known to affect the marine animals (Kumar \& Achyuthan, 2007).

Karachi is an incredibly significant coastal area for its aspect and financial bustle. There are in excess of 11,000 manufacturing units (CDGK, 2012) present, over 2,000 units in Federal-B-Area, 2.571 units in Korangi zone, 2.000 units in North Karachi, 1.200 units in Landhi zone and 4.000 units in Mangopir zone in Karachi (Ahmed et al., 2018). The removal of wastes in the shore supply a main cause of heavy metal input (Khattak et al., 2012; Mukhtar \& Hannan, 2012). From 92 naturally present elements, around 30 metals and metalloids are probably lethal to mankind for instance $\mathrm{Hg}, \mathrm{Cd}, \mathrm{Pb}, \mathrm{Cr}, \mathrm{Mn}, \mathrm{Ni}$, $\mathrm{Cu}$, As. The word of heavy metals having an atomic weight elevated than 40.04 (Appenroth, 2010) has been restored in years by a categorization system that reflect on their chemistry rather than essential density (Nieboer $\&$ Richardson, 1980). They are chemical elements with a 
specific gravity that is at least 5 times the specific gravity of water which is 1 at $4^{\circ} \mathrm{C}$ (Appenroth, 2010). Most of the modern techniques operated in the monitoring of seawater and sediment require timeconsuming and large-volume sampling, this demands substantial effort and cost unavoidable increases (Phillips \& Rainbow, 1998). Marine organisms have been known to accumulate significant amounts of heavy metals in their tissues (Bat \& Arıc1, 2018). Biological indicator species are studied to determine the metal pollution of the sea coasts (Bat et al., 1998-1999a; Gazioğlu 2018). These species are the very well-aimed to define organisms which accumulate contaminants especially metals in their tissues, and may consequently be analyzed to point out the abundance and bioavailable of such contaminants in marine coastal areas (Phillips \& Rainbow, 1998; Bat et al., 1998-1999b). Phillips \& Rainbow (1998) listed the following criteria (a) contaminants should be accumulated without lethal impacts to the species studied; (b) bio-indicator species should be sedentary, so as to be representative of the area in which they are collected; (c) low mortality percent under control conditions; (d) simple of collection; (e) provide sufficient tissue for contaminant analysis; and (f) a simple correlation should exist between the contaminant content in species and the average contaminant concentration in its ambient environment.

Presently gastropod mollusks are being exploit progressively as biomonitoring organisms (Vallaeys et al., 2017: Kelepertzis, 2013; Kumar \& Achyuthan, 2007) and are typically familiar to studied metals better than an assortment of further invertebrates (Bat \& Arıc1, 2018). The orders Patellogastropoda consists of the true limpets and make the primarily primitive group of current gastropods (Nakano \& Ozawa, 2007). The limpets fulfil many of criteria listed by Phillips and Rainbow (1998). They have been commonly employed in the monitoring of metal pollution in the coastal areas (Tuncer \& Yaramaz, 1982; Tuncer \& Uysal, 1988; Uysal et al., 1986; Uysal, 1992; Pastor et al., 1994; Bat et al., 1997; Bat et al., 2015).

Limpets are the best-known and also dominant organisms of the rocky intertidal and feed on a wide range of organisms and algae and encrusting red seaweed (Fish \& Fish, 1996). Limpets are known key species in rocky intertidal environment as they sustain the composition and formation of the community and when their territory vanish, grounds a jet consequence that affects the formation of the communities in which they exist (Raffaelli \& Hawkins, 1996). For instance, they manage barnacle numbers by eliminate the juvenile in their feeding passes, despite the fact that at the same time they limit the intensification of macroalgae, which could entirely obstruct barnacle recruitment (Branch, 1981). By occupy these mechanisms; the limpets sustain a variety of open places in the intertidal region that facilitate many species to coexist, as a result contributing to amplified marine biodiversity on rocky shores.
As a result, limpets perhaps the mainly essential group of grazers in moderate rocky intertidal zones (BurgosRubio et al., 2015). In particular, the limpet such as Patella sp. of rocky shores in Greek coasts, have an excellent ability to accrue metals, generally in their soft tissues (Collado et al., 2006). The true limpet (Cellana karachiensis) is commonly found in almost all rocky shores of Sind and Baluchistan coasts of Pakistan.

The present work is the first report on heavy metal levels in intertidal true limpet from the Karachi coast of Pakistan. The true limpet $C$. karachiensis were chosen for this study not only because of their abundance but also because the estimate of heavy metals intensity in this organism might provide an initiative of the level of nearshore metal pollution in selected two different rocky shores of the Karachi coast. C. karachiensis is commonly found in almost all rocky shores of Sind and Baluchistan coasts of Pakistan. The main objective of this study is to find out the levels of $\mathrm{Pb}$, $\mathrm{Zn}, \mathrm{Cd}, \mathrm{Cu}$ and $\mathrm{Cr}$ in the soft tissues of the common limpet $C$. karachiensis collected from the selected rocky shores of Karachi, and evaluate their heavy metals concentrations with data from limpets of other coastal environments in order to estimate the relative significance of contamination.

\section{Materials and Methods}

\section{Study Sites}

Pakistan hosts a coastline of $960 \mathrm{~km}$. It is divided into Sindh Coast (215 km long) and Baluchistan/Makran Coast $(745 \mathrm{~km}$ long). Both coastal zones are facing serious problems such as management of industrialized and household waste matter into the shallow marine environment or in the coastal water areas. The sea adjoining Pakistan Coast is very rich in marine ecosystem and its' economy can be supported if it is protected. This study was localized at two rocky shores i.e. Clifton and Mubarak village of Karachi coast (Figure 1) during the months of July and August 2019.We collected the samples of true limpets $C$. karachiensis to cover approx. 100 meters of both study sites (Figure 1).

\section{Collection of samples}

The study was carried out at high tidal zone during the months of July and August 2019. The limpets were collected from the top surfaces of the rocks, at the distance from the shoreline, so that limpets have experienced similar periods of emersion and immersion. The organisms were removed from the substratum with a plastic knife, washed with clean seawater, placed in clean plastic bags, transferred to the laboratory under cooling conditions. They were then rinsed with de ionized water to remove any debris or particles, measurement of shell length obtained, then freeze the samples at $-20 \mathrm{C}^{\mathrm{o}}$ until the digestion process begin. Sample preparation and analysis were carried out according to the procedure described by Bernhard (1976). 


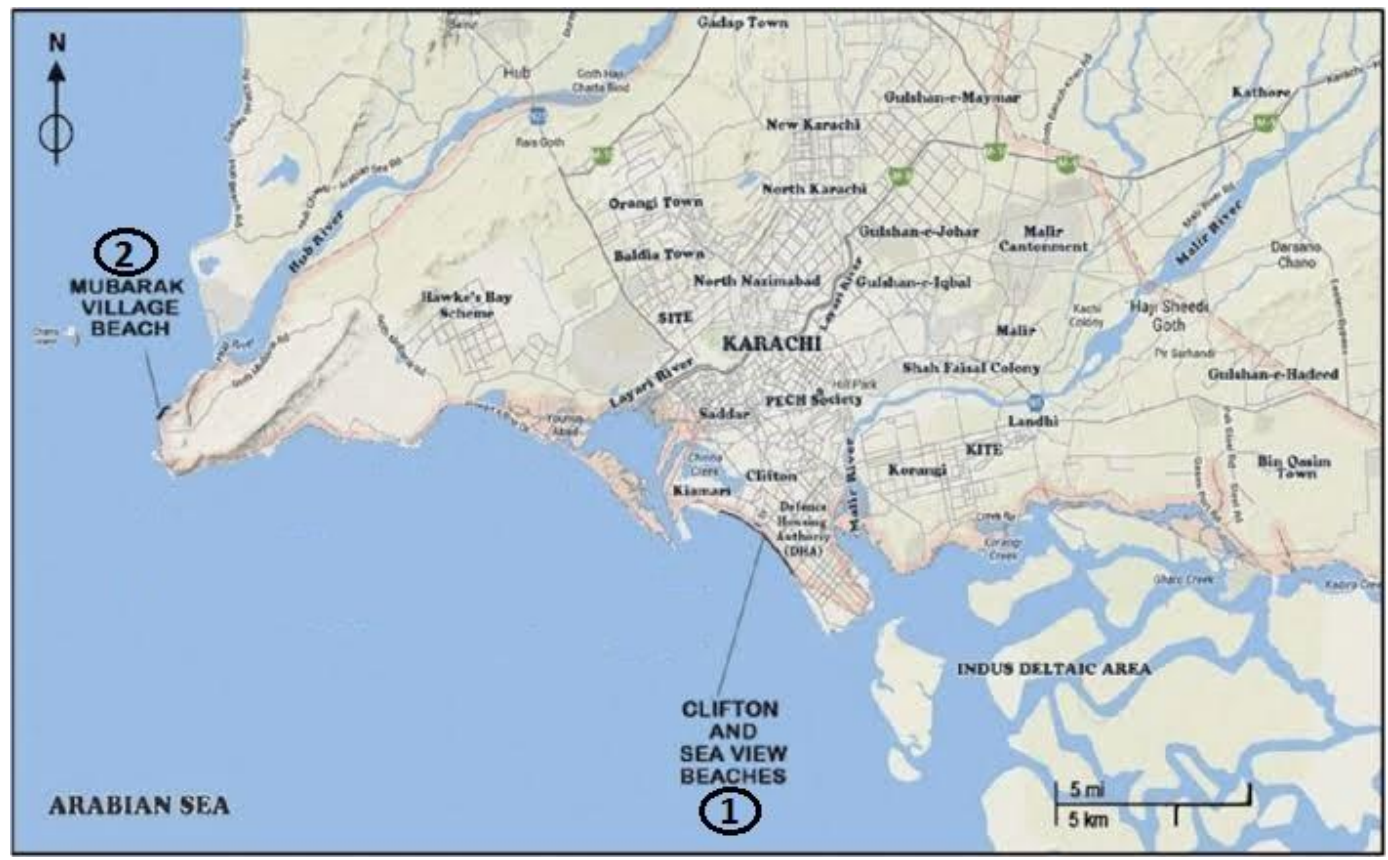

Fig 1. Map showing the sampling sites (Clifton and Mubarak village).

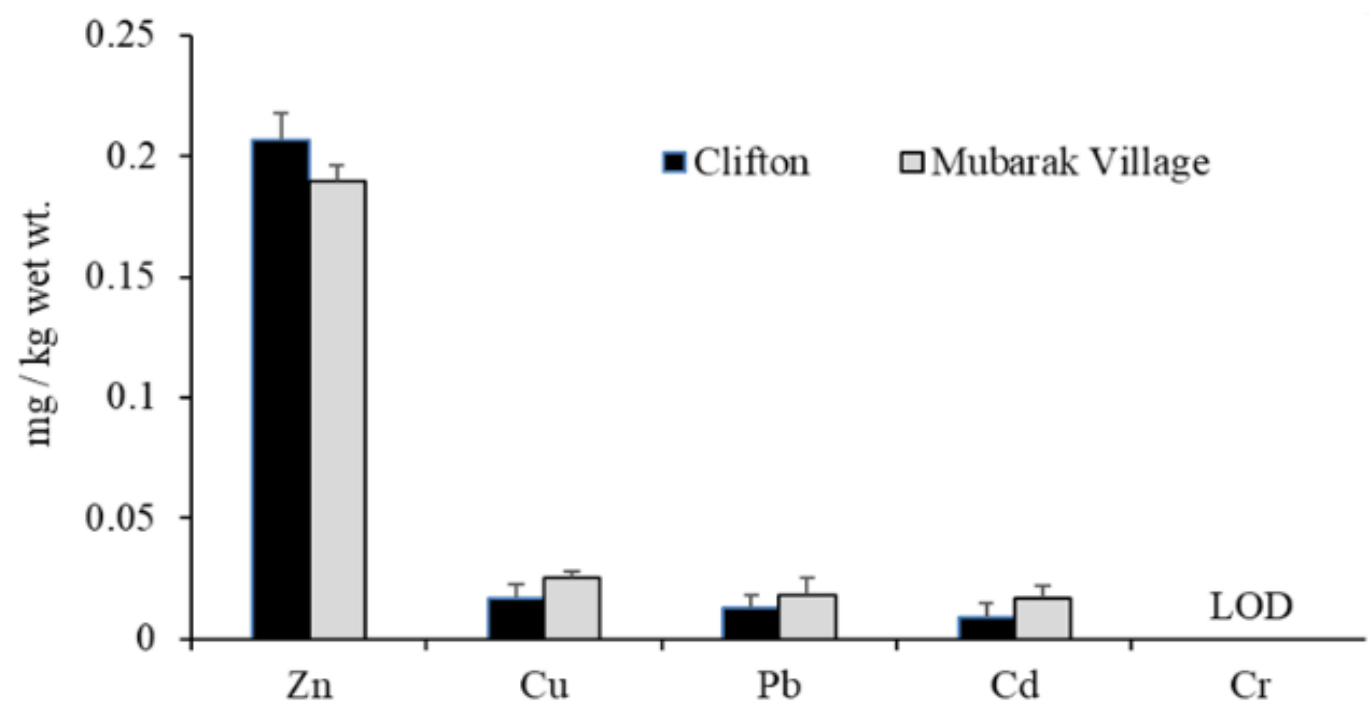

Fig 2. The means with standard deviations (vertical line) of $\mathrm{Zn}, \mathrm{Cd}, \mathrm{Cu}, \mathrm{Pb}$ and $\mathrm{Cr}$ concentrations in the soft tissue of $C$. karachiensis from two rocky shores of Karachi coast. 


\section{Analysis of the Heavy metals}

In laboratory the wet soft tissues were removed with a plastic knife and rinsed with double distilled water; the samples were divided into three groups. The samples were freeze-dried, samples were weighed accurate $5 \mathrm{~g}$ in 125-ml Erlenmeyer flask, added $25 \mathrm{ml}$ of de ionized water. A $10 \mathrm{ml}$ of 1:2 [equal volumes] mixture of concentrated $\mathrm{HNO}_{3}$ and $\mathrm{HClO}_{4}$ were added to each flask and the solution was evaporated to dryness on a hot plate until the solution were cleared. Transferred the solution quantitatively to a $100-\mathrm{ml}$ volumetric flask. Then it was diluted to volume with deionized water and mixed. After allowing the flasks to cool, the samples were diluted with double distilled water and filtered through Whatman filter paper for $\mathrm{Pb}, \mathrm{Zn}, \mathrm{Cd}, \mathrm{Cu}$ and $\mathrm{Cr}$ analysis on Atomic Absorption Spectrometer (A Analyst 700) using with a software (WinLab32 AA Flame - Lamp). Through this we run the program then turned the burner horizontally and vertically. Firstly, the calibration of sample standards (blank, 2, 4, 6) was done, after limpet samples were run. All samples were run in triplicate and all values were expressed as $\mathrm{mg}$ metal $\mathrm{kg}^{-1}$ wet wt.

\section{Statistical analysis}

Mean metal concentrations were calculated together with standard deviations; the standard deviations refer to the variability within different replicates. SPSS statistical package (Window version 18) and software Excel 2013 are used for data analysis. Results were interpreted by analyzing the data statistically by Analysis of variance (ANOVA) single factor for limpets to study the difference in accumulation pattern between the stations. Concentration of the analyzed heavy metals in $C$. karachiensis between Clifton and Mubarak village rocky shores was compared by the Student's t test. Differences were considered significant at the level of $\mathrm{P}<0.01$. Correlation study was also carried out for the metal concentration and animal shell length.

\section{Results}

\section{Length parameters}

Lengths of the true limpet varied from $12 \mathrm{~mm}$ to $34 \mathrm{~mm}$ with an average length $22.82 \pm 5.38 \mathrm{~mm}$ being observed at Clifton site and $20 \mathrm{~mm}$ to $43 \mathrm{~mm}$ with an average length $33.66 \pm 5.12$ have found at Mubarak Village shore (Table1).

Table 1. Mean \pm SD, minimum and maximum of length (mm) of true limpet Cellana karachiensis from rocky shores of Clifton and Mubarak Village

\begin{tabular}{cc}
\hline Sites & Mean \pm SD (min.-max.) \\
\hline Clifton & $22.82 \pm 5.38(12-34)$ \\
MubarakVillage & $33.66 \pm 5.12(20-43)$ \\
\hline
\end{tabular}

Heavy metal concentration in Cellana karachiensis Figure 2 shows the means amounts of $\mathrm{Zn}, \mathrm{Cr}, \mathrm{Cu}, \mathrm{Pb}$ and $\mathrm{Cd}$ as $\mathrm{mg} \mathrm{kg}^{-1}$ wet wt. in the soft tissue of $C$. karachiensis from two rocky shores of Karachi coast.
When compared the mean $\mathrm{Zn}, \mathrm{Cu}$ and $\mathrm{Cd}$ contents of true limpets between two rocky shores of Clifton and Mubarak Village, it is indicated that significantly different at $\mathrm{p}<0.01$. However, $\mathrm{Pb}$ values were found insignificant ( $p>0.01)$ for both regions (Table 2).

Table 2. Comparison between the mean metal content of limpets from rocky shores of Clifton and Mubarak Village.

\begin{tabular}{ccc}
\hline $\begin{array}{c}\text { Heavy } \\
\text { metals }\end{array}$ & $p$ - values & Significance level \\
\hline $\mathrm{Pb}$ & 0.1083 & $\begin{array}{c}\text { No significant difference }(p \\
>0.01)\end{array}$ \\
$\mathrm{Cd}$ & 0.00092 & $\begin{array}{c}\text { Significantly different }(p< \\
0.01)\end{array}$ \\
$\mathrm{Zn}$ & 0.00080 & $\begin{array}{c}\text { Significantly different }(p< \\
0.01)\end{array}$ \\
$\mathrm{Cu}$ & 0.0013 & $\begin{array}{c}\text { Significantly different }(p< \\
0.01) \\
---\end{array}$ \\
\hline $\mathrm{Cr}$ & -- & \\
\hline
\end{tabular}

Copper

Average $\mathrm{Cu}$ content of the limpets estimated was 0.017 ppm and $0.025 \mathrm{ppm}$ at Clifton and Mubarak village respectively. Statistical analysis revealed there is a significant difference in the $\mathrm{Cu}$ content of limpet between both shores at alpha 0.05 and 0.01 i.e. $(\mathrm{P}<0.05)$ and $(\mathrm{P}<0.01)$.

\section{Zinc}

$\mathrm{Zn}$ accumulated in the soft tissue of limpet was estimated $0.207 \mathrm{ppm}$ and $0.190 \mathrm{ppm}$ at Clifton and Mubarak village in that order. Statically accumulation of Zn did show significant difference between both shores at alpha 0.05 and 0.01 i.e. $(\mathrm{P}<0.05)$ and $(\mathrm{P}<0.01)$.

\section{Cadmium}

Average values of $\mathrm{Cd}$ ranged from $0.009 \mathrm{ppm}$ (Clifton) and $0.017 \mathrm{ppm}$ (Mubarak village). Concentration of $\mathrm{Cd}$ in the soft tissues of limpet also show significant difference between the shores at alpha 0.05 and 0.01 i.e. $(\mathrm{P}<0.05)$ and $(\mathrm{P}<0.01)$ studied.

\section{Lead}

Mean $\mathrm{Pb}$ content of the limpets estimated was $0.013 \mathrm{ppm}$ at Clifton and $0.018 \mathrm{ppm}$ at Mubarak village. ANOVA and "Student $t$ test". Statistical analysis revealed there was no significant difference between the $\mathrm{Pb}$ content of limpet at alpha 0.05 and 0.01 , i.e. $(\mathrm{P}>0.05)$ and $(\mathrm{P}>0.01)$.

\section{Chromium}

$\mathrm{Cr}$ values in the true limpets were found below the limits of detection (LOD) in both locations, indicating nonsignificant difference between the shores.

\section{Correlation of Heavy Metals with shell length at Clifton site}

Correlation of $\mathrm{Pb}, \mathrm{Cu}, \mathrm{Zn}, \mathrm{Cd}$ and $\mathrm{Cr}$ content with limpet shell length was studied and results are interpreted in Table 3 . 
Table 3. Correlation of Heavy Metals with other limpet shell length at Clifton site (+ Positive Correlation, Negative Correlation)

\begin{tabular}{llllll} 
Metals & $\mathrm{Pb}$ & $\mathrm{Zn}$ & $\mathrm{Cd}$ & $\mathrm{Cu}$ & $\mathrm{Cr}$ \\
Length & +0.267 & -0.213 & +0.017 & +0.36 & -0.56 \\
\hline
\end{tabular}

\section{Correlation of heavy metals with shell length at} Mubarak Village site

Correlation of $\mathrm{Pb}, \mathrm{Cu}, \mathrm{Zn}, \mathrm{Cd}$ and $\mathrm{Cr}$ accumulation with limpet shell length was studied and results are interpreted in Table 4.

Table 4. Correlation of Heavy Metals with other limpet shell length at Mubarak Village site (+ Positive Correlation, - Negative Correlation, * Significant correlation)

\begin{tabular}{llllll}
\hline Metals & $\mathrm{Pb}$ & $\mathrm{Zn}$ & $\mathrm{Cd}$ & $\mathrm{Cu}$ & $\mathrm{Cr}$ \\
Length & $0.72 *$ & -0.216 & +0.10 & -0.11 & 0.05 \\
\hline
\end{tabular}

\section{Discussion and Conclusion}

The heavy metal concentrations show variations depending on the locality. $\mathrm{Cr}$ values were below the limit of detection (LOD) of atomic absorption spectrometer in all samples. $\mathrm{Zn}$ values were higher in true limpet collected from Clifton region, whereas $\mathrm{Cu}, \mathrm{Pb}$ and $\mathrm{Cd}$ values were higher in those collected from Mubarak Village. It can be said that these differences, which are statistically significant, result from geographical location differences. On the other hand, this may be due to the discharge of untreated domestic wastes, the dumping of ship wastes, harbor activities and other coastal activities. $\mathrm{Zn}$ was found in highest concentrations in the true limpet at both locations. In general, the concentrations of studied elements $C$. karachiensis from two rocky shores of Karachi coast are as fallow: $\mathrm{Zn}>\mathrm{Cu}>\mathrm{Pb}>\mathrm{Cd}$ at Clifton and Mubarak Village. Many metals are essential to biota such that in their absence an organism can neither grow nor reproduce. All metals are taken up by aquatic organisms from solution and food or particles. In the present study the essential metals $\mathrm{Zn}, \mathrm{Cr}$ and $\mathrm{Cu}$ levels being consistently higher in the true limpet while the reverse condition existing for non-essential metals $\mathrm{Pb}$ and $\mathrm{Cd}$. Non-essential heavy metals are harmful and toxic to organisms, even in trace amounts. Heavy metals, which are essential for living organisms, do not harm low amounts in organisms. However, they are poisonous in excess. The European Commission Regulation does not have maximum acceptable values for essential metals in seafood. The European Commission Regulation (2006) indicated the maximum amount of $\mathrm{Pb}$ and $\mathrm{Cd}$ in mollusks 1.5 and $1.0 \mathrm{mg} \mathrm{kg}^{-1}$ wet wt., respectively. In the present study, the mean $\mathrm{Pb}$ and $\mathrm{Cd}$ levels, obtained for the true limpet were $0.0155 \pm 0.006$ and $0.013 \pm 0.0055 \mathrm{mg} \mathrm{kg}^{-1}$ wet wt., respectively and these amounts were quite below the limit values. Mollusks species are accepted as good bio indicators considering their ability to filter large volumes of sea water and thus to accumulate trace elements. As sessile species presenting increased longevity, they constitute interesting bio indicators in long term impact studies in given habitats (Espinosa et al., 2007; Huang et al., 2007). Several authors have studied the effects of the age, weight or size of the organism in the accumulation of heavy metals and reported that the trace metal concentrations within mollusks are dependent on size (Romeril, 1971; Raymont, 1972; Boyden 1974; Phillips, 1979a, b; Boalch et al., 1981; Bat et al., 2018). In the present study all heavy metals except $(\mathrm{Cu})$ showed positive correlation with length of the limpet at both study sites while negative correlation of $\mathrm{Cu}$ with length of the animal at Mubarak village site has been observed. Mackay et al. (1975) asserted that metal concentrations decrease with increasing age and wet weight of oysters. Raymont (1972) have reported an increase in concentrations of zinc, copper and iron with increased age of Mercenaria mercenaria. Boyden (1974) reported relationships between size of organism, metal concentration and total metal content for several species of bivalves. Phillips $(1979 a, b)$ stated that, in the environment, smaller individuals of Mytilus edulis were found to contain significantly higher concentrations of zinc, cadmium, lead and copper than larger individuals. Again Phillips (1979b) reported that the size or weight dependent variation in concentrations of metals is by no means always the same, as the incidence of significant relationships between tissue size and metal concentration vary with season and between metals. Apart from these it is reported by many authors that in bivalves, $\mathrm{Cd}$ concentrations either decrease with growth remaining unchanged, or increase with age (Boyden, 1974; Szefer \& Szefer, 1985). From the present study it is also understood that the size dependent variation in concentrations of metals is by no means always the same. Correlation in shell length of the true limpet and heavy metals content at Clifton and Mubarak village shows positive correlation while $\mathrm{p}$ values of regression shows no significant result i.e. $\mathrm{p}>0.05$. Only at Mubarak Village $\mathrm{Cu}$ and shell length correlation shows negative and significant difference $\mathrm{p}<0.05$.

In the present study, the concentrations of metals found in C. karachiensis, would appear to be lower, in general, than those found in Patella spp. from different seas. In Table 5, results of the present study are compared with some other studies. Bat et al. (1997) pointed out that regional comparison for results must be made with caution because of variations in both the quality of analytical data and in sampling procedure. The most probably reason for the differences in the amount of heavy metal in the limpets is due to geographical differences. Results of this study, however, indicate that the amounts obtained are allowable limits when compared with those of similar investigations carried out in the parts of different seas.

Many of the results in Table 5 conclude that the higher values have been determined near known sources of anthropogenic inputs. Heavy metal levels in $C$. karachiensis were determined for the first time in Karachi by this study. The true limpet shows to be useful bio-indicator because of their accumulation of the metals and continued sampling and individual tissue analysis are required for further investigations. 
Table 5. Heavy metal levels in limpets (expressed in $\mathrm{mg}$ metal $\mathrm{kg}^{-1}$ wet wt., * dry wt.).

\begin{tabular}{|c|c|c|c|c|c|c|c|}
\hline Species & Study Area & $\mathrm{Zn}$ & $\mathrm{Cr}$ & $\mathrm{Cu}$ & $\mathrm{Pb}$ & $\mathrm{Cd}$ & Ref. \\
\hline Cellana karachiensis & Karachi coasts & $0.19-0.207$ & LOD & $0.017-0.025$ & $0.013-0.018$ & $0.009-0.017$ & This study \\
\hline Patella caerula & Black Sea & $1.43-4.72$ & -- & $0.47-1.64$ & $0.02-0.057$ & $0.02-0.049$ & Bat et al.,1997 \\
\hline Patella caerula & Black Sea & $12-23$ & -- & $<0.61-0.85$ & $<0.05-0.19$ & $<0.02-0.04$ & Bat et al., 2015 \\
\hline Patella caerula & Mediterranean Sea & -- & -- & -- & $0.67-1.29$ & $0.15-0.75$ & Pastor et al.,1994 \\
\hline Patella vulgata & Somerset & $9.7-143$ & -- & $2.0-12$ & $0.17-0.75$ & $0.9-118.5$ & Peden et al., 1973 \\
\hline Patella vulgata & Aegean Sea & $14.3-37.9$ & -- & $2.99-3.37$ & $0.47-2.27$ & $0.18-0.17$ & Tuncer \& Yaramaz, 1982 \\
\hline Patella vulgata & Aegean Sea & $10.9-24.5$ & -- & $1.77-3.73$ & $1.64-5.00$ & $0.21-0.59$ & Uysal et al., 1986 \\
\hline Patella vulgata & Izmir Bay & $3.92-27.7$ & -- & $1.41-7.97$ & $1.36-8.85$ & $0.11-1.99$ & Tuncer \& Uysal, 1988 \\
\hline Patella sp. & Aegean Sea & $42.6-93.5$ & -- & $2.15-4.26$ & $1.23-5.00$ & $0.78-5.56$ & Uysal, 1992 \\
\hline Patella sp.* & Stratoni and Artemida & 48-196 & $7-8$ & 6-28 & $8-96$ & -- & Kelepertzis, 2013 \\
\hline Patella rustica* & Canary Islands & $0.14-33.23$ & -- & $0.1-5.01$ & $0.33-3.4$ & $0.02-2.48$ & Collado et al., 2006 \\
\hline P. candei crenata* & Canary Islands & $11.31-72.54$ & -- & $0.71-6.73$ & $0.01-0.55$ & $0.08-9.16$ & Collado et al., 2006 \\
\hline Patella caerula & Ras Beirut coasts & -- & -- & $2.7-9.7$ & $<1.4-27.5$ & $0.1-1.1$ & Shiber \& Shatila, 1978 \\
\hline Patella piperata* & Canary Island & $1.61-24.06$ & -- & $0.6-5.01$ & $0.332-10.213$ & $0.023-0.941$ & Bergasa et al., 2007 \\
\hline Patella vulgata* & Goury & $40-91$ & $0.2-2.4$ & $3.0-6.6$ & 0.9-3.7 & $2.7-7.5$ & Miramand \& Bentley,1992 \\
\hline Patella sp.* & Mediterranean Sea & 44-96 & $1.5-10.6$ & $3.5-13.7$ & $0.3-3.2$ & $2.1-30.3$ & Ramelow, 1985 \\
\hline Patella caerula* & Gulf of Suez & $56.47-191.42$ & $2.34-7.99$ & $1.61-12.17$ & $6.23-70.91$ & $0.63-2.13$ & Hamed \& Emara, 2006 \\
\hline Patella caerulea* & Mediterranean Sea & $2 . .13-46.59$ & $4.77-8.33$ & $1.58-4.02$ & $4.28-14.53$ & $2.39-4.97$ & Türkmen et al., 2005 \\
\hline Patella aspera* & Portugal coast & $36.1-172$ & -- & $3.54-15.2$ & LOD & $1.03-9.19$ & Cravo \& Bebianno, 2005 \\
\hline Patella sp.* & Spain coats & $90-120$ & -- & $5-10$ & $2-16$ & $1.1-7.1$ & Stenner \& Nickless, 1975 \\
\hline
\end{tabular}




\section{Conflict of interest statement}

We declare that we have no conflict of interest.

\section{References}

Ahmed, Q., Bat, L, Öztekin, A., Ali, Q. M. (2018). A review on studies of heavy metal determination in mackerel and tuna (Family-Scombridae) fishes. Journal of Anatolian Environmental and Animal Sciences, 3(3), 106-122.

Appenroth, K.J. (2010). Chapter 2 Definition of "Heavy metals" and their role in biological systems. In: I. Sherameti and A. Varma (eds.), Soil Heavy Metals. Soil Biology, (19), doi.org/19-29. 10.1007/978-3642-02436-8_2

Bat, L., Ar1c1, E. (2018). Chapter 5. Heavy Metal Levels in Fish, Molluscs, and Crustacea From Turkish Seas and Potential Risk of Human Health. In: Holban AM, Grumezescu AM. (Eds.) Handbook of Food Bioengineering, Volume 13, Food Quality: Balancing Health and Disease. Elsevier, Academic Press, pp. 159-196.

Bat, L., Arici, E., Öztekin, A. (2018). Human health risk assessment of heavy metals in the Black Sea: evaluating mussels. Current World Environment, 13(1), 15-31 doi.org/10.12944/CWE.13.1.03

Bat, L., Öztürk, M., Öztürk, M. (1998-1999a). Aquatic toxicology. S.D.Ü. Eğirdir Su Ürünleri Fak. Der, 6, 148-165 (in Turkish).

Bat, L., Gündoğdu, A., Öztürk, M. (1998-1999b). Heavy metals. S.D.Ü. Eğirdir Su Ürünleri Fak. Der, 6, 166175 (in Turkish).

Bat, L., Öztürk, M., Öztürk, M. (1997). Patella caerula as a biomonitor of coastal metal pollution. II. Spil Fen Bilimleri Serisi (Biyoloji), 23-25.

Bat, L., Yardim, Ö., Arici, E., Öztekin, A. (2015). Current status of heavy metals in soft tissues of the limpet Patella caerulea (Linnaeus, 1758) from Sinop coast of the Black Sea. Pakistan Journal of Marine Sciences, 24(1\&2), 29-35.

Bergasa, O., Ramírez, R., Collado, C., Hernández-Brito, J. J., Gelado-Caballero, M. D., Rodríguez-Somozas, M., Haroun, R. J. (2007). Study of metals concentration levels in Patella piperata throughout the Canary Islands, Spain. Environmental Monitoring and Assessment, 127(1-3), 127-133. doi.org/10.1007/s10661-006-9266-x

Bernhard, M. (1976). Manual of Methods in Aquatic Environment Research. Part 3. Sampling and Analysis of Biological Material, Fisheries Technical Paper FIRI / T, Rome. No. 158.

Boalch, R., Chan, S., Taylor, D. (1981). Seasonal variation in the trace metal content of Mytilus edulis. Marine Pollution Bulletin, 12 (8), 276-280. doi.org/10.1016/0025-326X(81)90451-3

Boyden, C. R. (1974). Trace element content and body size in molluscs. Nature, 251(5473), 311-314. doi.org/10.1038/251311a0

Branch, G.M. (1981). The biology of limpets: physical factors, energy flow, and ecological interactions. Oceanogr. Mar. Biol. Ann. Rev., 19, 235-380.
Burak, S. Doğan, E. and Gazioğlu, C. (2004). Impact of urbanization and tourism on coastal environment. Ocean and Coastal Management , 47(9), 515-527, doi.org/10.1016/j.ocecoaman.2004.07.007.

Burgos-Rubio, V., De la Rosa, J., Altamirano, M., Espinosa, F. (2015). The role of patellid limpets as omnivorous grazers: a new insight into intertidal ecology. Marine Biology, 162(10), 2093-2106. doi.org/10.1007/s00227-015-2739-0

CDGK (2012). City district Government of Karachi. www.karachicity.gov.pk

Collado, C., Ramírez, R., Bergasa, O., Hernández-Brito, J. J., Gelado-Caballero, M. D., Haroun, R. J. (2006). Heavy metals $(\mathrm{Cd}, \mathrm{Cu}, \mathrm{Pb}$ and $\mathrm{Zn})$ in two species of limpets (Patella rustica and Patella candei crenata) in the Canary Islands, Spain. Water Pollution VIII: Modelling, Monitoring and Management, 1, 45-53. doi.org/10.2495/WP060051

Cravo, A., Bebianno, M. J. (2005). Bioaccumulation of metals in the soft tissue of Patella aspera: Application of metal shell weight indices. Estuarine, Coastal and Shelf Science, 65 (3), 571-586. doi.org/10.1016/j.ecss.2005.06.026

Espinosa, F., Guerra-García, J. M., García-Gómez, J. C. (2007). Sewage pollution and extinction risk: an endangered limpet as a bioindicator?. Biodiversity and Conservation, 16(2), 377-397. doi.org/10.1007/s10531-005-3014-3

European Union Commission Regulation. (2006). Official Journal of the European Union. Setting maximum levels for certain contaminants in food stuffs. Commission Regulation (EC) No 1881, 364, 5-24.

Fish, J. D., Fish, S. (1996). A student's guide to the seashore. Second edition Cambridge University Press, England.

Gazioğlu, C. (2018). Biodiversity, Coastal Protection, Promotion and Applicability Investigation of the Ocean Health Index for Turkish Seas, International Journal of Environment and Geoinformatics, 5(3), 353-367, doi.org/10.30897/ijegeo.484067.

Hamed, M. A., Emara, A. M. (2006). Marine molluscs as biomonitors for heavy metal levels in the Gulf of Suez, Red Sea. Journal of Marine Systems, 60 (3-4), 220-234. doi.org/10.1016/j.jmarsys.2005.09.007

Huang, H., Wu, J. Y., Wu, J. H. (2007). Heavy metal monitoring using bivalved shellfish from Zhejiang coastal waters, East China Sea. Environmental monitoring and assessment, 129 (1-3), 315-320. doi.org/10.1007/s10661-006-9364-9

Kelepertzis, E. (2013). Heavy metals baseline concentrations in soft tissues of Patella sp. from the Stratoni coastal environment, Ne Greece. Ecological Chemistry and Engineering S, 20 (1), 141-149. doi.org/10.2478/eces-2013-0011

Khattak, M. I., Khattak, M. I., Mohibullah, M. (2012). Study of heavy metal pollution in mangrove sediments reference to marine environment along the coastal areas of Pakistan. Pak. J. Bot., 44(1), 373378.

Kumar, K. A., Achyuthan, H. (2007). Heavy metal accumulation in certain marine animals along the 
East Coast of Chennai, Tamil Nadu, India. Journal of environmental biology, 28 (3), 637-643.

Mackay, N. J., Williams, R. J., Kacprzac, J. L., Kazacos, M. N., Collins, A. J., Auty, E. H. (1975). Heavy metals in cultivated oysters (Crassostrea commercialis = Saccostrea cucullata) from estuaries of New South Wales. Marine and Freshwater Research, 26 (1), 31-46 doi.org/10.1071/MF9750031

Miramand, P., Bentley, D. (1992). Heavy metal concentrations in two biological indicators (Patella vulgata and Fucus serratus) collected near the French nuclear fuel reprocessing plant of La Hague. Science of the Total Environment, 111(2-3), 135-149. doi.org/10.1016/0048-9697(92)90352-S

Mukhtar, I., Hannan, A. (2012). Constrains on mangrove forests and conservation projects in Pakistan. Journal of Coastal Conservation, 16(1), 51-62. doi.org/10.1007/s11852-011-0168-X

Nakano, T., Ozawa, T. (2007). Worldwide phylogeography of limpets of the order Patellogastropoda: molecular, morphological and palaeontological evidence. Journal of Molluscan Studies, 73 (1), 79-99.

Nieboer, E., Richardson, D. H. (1980). The replacement of the nondescript term 'heavy metals' by a biologically and chemically significant classification of metal ions. Environmental Pollution Series B, Chemical and Physical, 1(1), 3-26.

Pastor, A., Hernandez, F., Peris, M. A., Beltran, J., Sancho, J. V., Castillo, M. T. (1994). Levels of heavy metals in some marine organisms from the western Mediterranean area (Spain). Marine Pollution Bulletin, 28 (1), 50-53. doi.org/10.1016/0025326X(94)90186-4

Peden, J. D., Crothers, J. H., Waterfall, C. E., Beasley, J. (1973). Heavy metals in Somerset marine organisms. Marine Pollution Bulletin, 4 (1), 7-9. doi.org/10.1016/0025-326X(73)90022-2

Phillips, D. J. (1979a). Trace metals in the common mussel, Mytilus edulis (L.), and in the alga Fucus vesiculosus (L.) from the region of the Sound (Öresund). Environmental Pollution, 18(1), 31-43. doi.org/10.1016/0013-9327(79)90031-4

Phillips, D. J. H. (1979b). The rock oyster Saccostrea glomerata as an indicator of trace metals in Hong Kong. Marine Biology, 53 (4), 353-360. DOI: 10.1007/BF00391618

Phillips, D. J., Rainbow, P. S. (1998). Biomonitoring of trace aquatic contaminants (Vol. 37). Springer Science \& Business Media.

Raffaelli, D., Hawkins, S. J. (1996). Intertidal ecology. Chapman and Hall, London.

Ramelow, G. J. (1985). A study of heavy metals in limpets Patella sp. collected along a section of the Southeastern Turkish Mediterranean coast. Marine environmental Research, 16 (4), 243-253. doi.org/10.1016/0141-1136(85)90022-4

Raymont, J. E. G. (1972). Some aspects of pollution in Southampton Water. Proceedings of the Royal Society of London. Series B. Biological Sciences, 180 (1061), 451-468.
Romeril, M. G. (1971). The uptake and distribution of 65 $\mathrm{Zn}$ in oysters. Marine Biology, 9 (4), 347-354. doi.org/10.1007/BF00372829

Shiber, J. G., Shatila, T. A. (1978). Lead, cadmium, copper, nickel and iron in limpets, mussels and snails from the coast of Ras Beirut, Lebanon. Marine Environmental Research, 1(2), 125-134. doi.org/10.1016/0141-1136(78)90005-3

Stenner, R. D., Nickless, G. (1975). Heavy metals in organisms of the Atlantic coast of SW Spain and Portugal. Marine Pollution Bulletin, 6(6), 89-92. doi.org/10.1016/0025-326X(75)90151-4

Szefer, P., Szefer, K. (1985). Occurrence of ten metals in Mytilus edulis L. and Cardium glaucum L. from the Gdańsk Bay. Marine Pollution Bulletin, 16(11), 446450. doi.org/10.1016/0025-326X(85)90415-1

Tuncer, S., Uysal, H. (1988). İzmir ve Candarlı (Aliağa Limanı) Körfezi’nde yaşayan bazı Mollusk türlerinde ağır metal kirlenmesi ile ilgili araştırmalar. Doğa TU. Müh. ve Çev., 12(3), 350-368.

Tuncer, S., Yaramaz, O. (1982). Etude des métaux lourds chez les mollusques dans les différentes zones de la baie d'Izmir (Turquie). 5èmes journées d'étude sur les pollutions. Cannes, CIESM, pp. 307-313.

Türkmen, M., Türkmen, A., Akyurt, I., Tepe, Y. (2005). Limpet, Patella caerulea Linnaeus, 1758 and barnacle, Balanus sp., as biomonitors of trace metal availabilities in Iskenderun Bay, northern east Mediterranean sea. Bulletin of Environmental Contamination and Toxicology, 74(2), 301-307. doi.org/10.1007/s00128-004-0584-9

Uysal, H. (1992). Heavy metal concentrations in selected marine species from fishers bays of Aegean coast. Rapp. CommJnt. Mer. Medit, 33.

Uysal, H., Tuncer, S., Yaramaz, Ö. (1986). Ege kıyılarındaki yenebilen organizmalarda ağır metallerin karşılaştırmalı olarak araştırılması. Çev. Kong, 86, 2-5. (in Turkish).

Vallaeys, T., Klink, S. P., Fleouter, E., Le Moing, B., Lignot, J. H., Smith, A. J. (2017). Bioindicators of marine contaminations at the frontier of environmental monitoring and environmental genomics. Adv Biotech \& Micro., 4(1), 555629. doi.org/10.19080/AIBM.2017.04.555629. 